\title{
Ex Situ Poly(3,4-ethylenedioxythiophene)-sodium Dodecyl Sulfate-Antimony Film Electrode for Anodic Stripping Voltammetry Determination of Lead and Cadmium.
}

\author{
Edgar Nagles ${ }^{1, *}$, Olimpo García-Beltrán ${ }^{1}$, John Hurtado ${ }^{2}$ \\ ${ }^{1}$ Facultad de Ciencias Naturales y Matemáticas, Universidad de Ibagué, Carrera 22 Calle 67, \\ Ibagué730001, Colombia \\ ${ }^{2}$ Departamento de Química, Universidad de los Andes, Carrera 1 No. 18A-12, Bogotá, Colombia. \\ *E-mail: edgar.nagles@unibague.edu.co
}

doi: $10.20964 / 2016.09 .28$

Received: 11 May 2016 / Accepted: 30 June 2016 / Published: 7 August 2016

\begin{abstract}
A poly(3,4-ethylenedioxythiophene)-sodium dodecyl sulfate coated antimony film electrode PEDOTSDS-SbFE was prepared ex situ and applied to determine $\mathrm{Pb}(\mathrm{II})$ and $\mathrm{Cd}(\mathrm{II})$ by anodic stripping voltammetry (ASV). The PEDOT-SDS-SbFE exhibited well developed signals for the oxidation of $\mathrm{Pb}$ and $\mathrm{Cd}$ at -0.12 and $-0.40 \mathrm{~V}$ respectively, with higher current compared to unmodified electrodes. The optimum parameters for PEDOT-SDS-SbFE preparation consisted in an EDOT 0.01 mol L${ }^{-1}$ in $\mathrm{KCl} 0.1 \mathrm{~mol} \mathrm{~L}^{-1}$ with SDS $1.0 \times 10^{-3} \mathrm{~mol} \mathrm{~L}^{-1}$ solution at scanning rate of $50 \mathrm{mVs}^{-1}(10$ cycles $-0.1 \mathrm{a} 1.6 \mathrm{~V}), 200 \mathrm{mg} \mathrm{L}^{-1} \mathrm{Sb}(\mathrm{III})$ in $0.5 \mathrm{~mol} \mathrm{~L}^{-1} \mathrm{HCl}$ at $-1.2 \mathrm{~V}(150 \mathrm{~s})$ and for the determination of $\mathrm{Pb}$ (II) and $\mathrm{Cd}(\mathrm{II})$ were $\mathrm{pH}=4.0$ (acetate buffer); Eacc $=-1.0 \mathrm{~V}$ and tacc $=60 \mathrm{~s}$. The electrode showed good linear behavior in concentration range from 4.5 to $140.0 \mu \mathrm{g} \mathrm{L}^{-1}$ for both metal ions. The limit of detection $(3 \sigma)$ was 0.50 and $0.80 \mu \mathrm{g} \mathrm{L}^{-1}$ for $\mathrm{Pb}(\mathrm{II})$ and $\mathrm{Cd}(\mathrm{II})$ respectively. The RSD for a $\mathrm{Pb}$ (II) a $\mathrm{Cd}$ (II) $47.0 \mu \mathrm{g} \mathrm{L}{ }^{-1}$ was $1.5 \%$ for seven successive assays. The method was validated using model solutions with satisfactory results. The method was applied to the determination of $\mathrm{Pb}(\mathrm{II})$ and $\mathrm{Cd}(\mathrm{II})$ in commercial mineral water and river water samples.
\end{abstract}

Keywords: Electrochemically deposited PEDOT; Antimony film; SDS; Chemically modified electrode; Cadmium and lead.

\section{$\underline{\text { FULL TEXT }}$}

(C) 2016 The Authors. Published by ESG (www.electrochemsci.org). This article is an open access article distributed under the terms and conditions of the Creative Commons Attribution license (http://creativecommons.org/licenses/by/4.0/). 